\title{
Birdshot retinochoroidopathy and subretinal new
} vessels

\author{
G. SOUBRANE, ${ }^{1}$ G. COSCAS,${ }^{1}$ M. BINAGHI, ${ }^{1}$ P. AMALRIC,${ }^{2}$ AND J. A. BERNARD ${ }^{3}$ \\ From the ${ }^{1}$ Eye University Clinic of Creteil, ${ }^{2} 6$ rue Saint Clair, 81000 ALBI, and \\ ${ }^{3}$ Eye University Clinic Cochin, France
}

SUMMARY Decrease of visual acuity in birdshot retinochoroidopathy is due either to optic atrophy or to 3 types of macular involvement: cystoid macular oedema, geographic atrophy, or macular serous detachment. We describe 3 cases of juxtapapillary subretinal neovascularisation occurring in long-standing birdshot retinochoroidopathy. The mechanism of the formation of the new vessels is discussed.

Birdshot retinochoroidopathy was first described by Ryan and Maumenee in $1980 .^{1}$ This bilateral syndrome is a chronic disease with exacerbations and remissions. It is characterised by bilateral vitreous inflammation with no 'snow-bank' exudates overlying the pars plana, diffuse retinal vasculitis, and multifocal patches of depigmentation of the choroid and of the pigment epithelium in the postequatorial fundi. These characteristic lesions led Gass $^{2}$ to propose the term of 'vitiliginous chorioretinitis' because of the association in some patients of this disorder with vitiligo. Papillary involvement is usual: mostly papillitis, sometimes optic atrophy. ${ }^{1-3}$ Three types of macular involvement were described: cystoid macular oedema, ${ }^{124}$ geographic atrophy of the macula,${ }^{1-3}$ and macular serous detachment. ${ }^{12}$

Macular subretinal neovascularisation has been described in numerous ocular diseases: senile macular degeneration, ${ }^{5}$ degenerative myopia, ${ }^{5}$ presumed histoplasmosis syndrome, ${ }^{, \rightarrow}$ acute posterior multifocal placoid pigment epitheliopathy, ${ }^{10}$ serpiginous choroiditis, ${ }^{1112}$ toxocara canis, ${ }^{1013}$ chronic uveitis, ${ }^{14} 15$ coccidioidomycosis, ${ }^{10}$ drusen of the optic disc, ${ }^{16}{ }^{17}$ choroidal naevi, ${ }^{18-21}$ melanoma and choroidal haemangioma, ${ }^{1018}$ choroidal metastasis, ${ }^{1018}$ choroidal rupture, ${ }^{22} 23$ angioid streaks, ${ }^{24} 25$ pigment epithelial hamartomas, ${ }^{26}$ fundus flavimaculatus, ${ }^{27}$ vitelliform macular dystrophy ${ }^{28}$ and after argon laser photocoagulation. ${ }^{2930}$ These new vessels were also described in systemic diseases: Groenblad-Strandberg syndrome ${ }^{24}$ Paget's disease, ${ }^{25}$ Ehlers-Danlos disease, ${ }^{10}$ sickle cell haemoglobinopathies, ${ }^{31-33}$

Correspondence to Eye University Clinic of Creteil, 40 Avenue de Verdun, 94010 Creteil, France. sarcoidosis, ${ }^{10}$ pseudotumour cerebri, ${ }^{3435}$ rubella, ${ }^{36-38}$ Behçet's disease ${ }^{39}$ and Vogt-Koyanagi-Harada syndrome. ${ }^{40}$

Although macular scars thought to be secondary to disciform macular degeneration ${ }^{41}{ }^{42}$ have been observed, we believe there is no published report of active subretinal neovascularisation associated with birdshot retinochoroidopathy. We here report 3 such cases.

\section{Case reports}

CASE 1

In March 1981 we examined a 40-year-old woman with a history of decreased visual acuity and metamorphopsia of the left eye for one month. Her family history was not relevant. There was no evidence of systemic disease, although she had transient hypertension during one pregnancy and was moderately obese. Laboratory studies showed a reduction of the $\mathrm{C} 4$ fraction of complement and the presence of antigen HLA B5.

On examination her best corrected visual acuity was RE 6/6 (with $-3.75(-1.25) \times 115)$ and LE 6/9 (with $-2 \cdot 75(-100) \times 20)$. There was a mild cellular reaction in the anterior chambers. Applanation tonometry was normal. Biomicroscopy disclosed cells diffusely throughout the vitreous of both eyes. There were scattered, discrete, cream coloured hypopigmented subretinal patches in both eyes. Most were less than 1 disc diameter, but in the inferior nasal quadrant some were confluent (Fig. 1). Large choroidal blood vessels appeared normal. There was mild blurring of the disc margins. The hypopigmented patches were less prominent angiographically than 


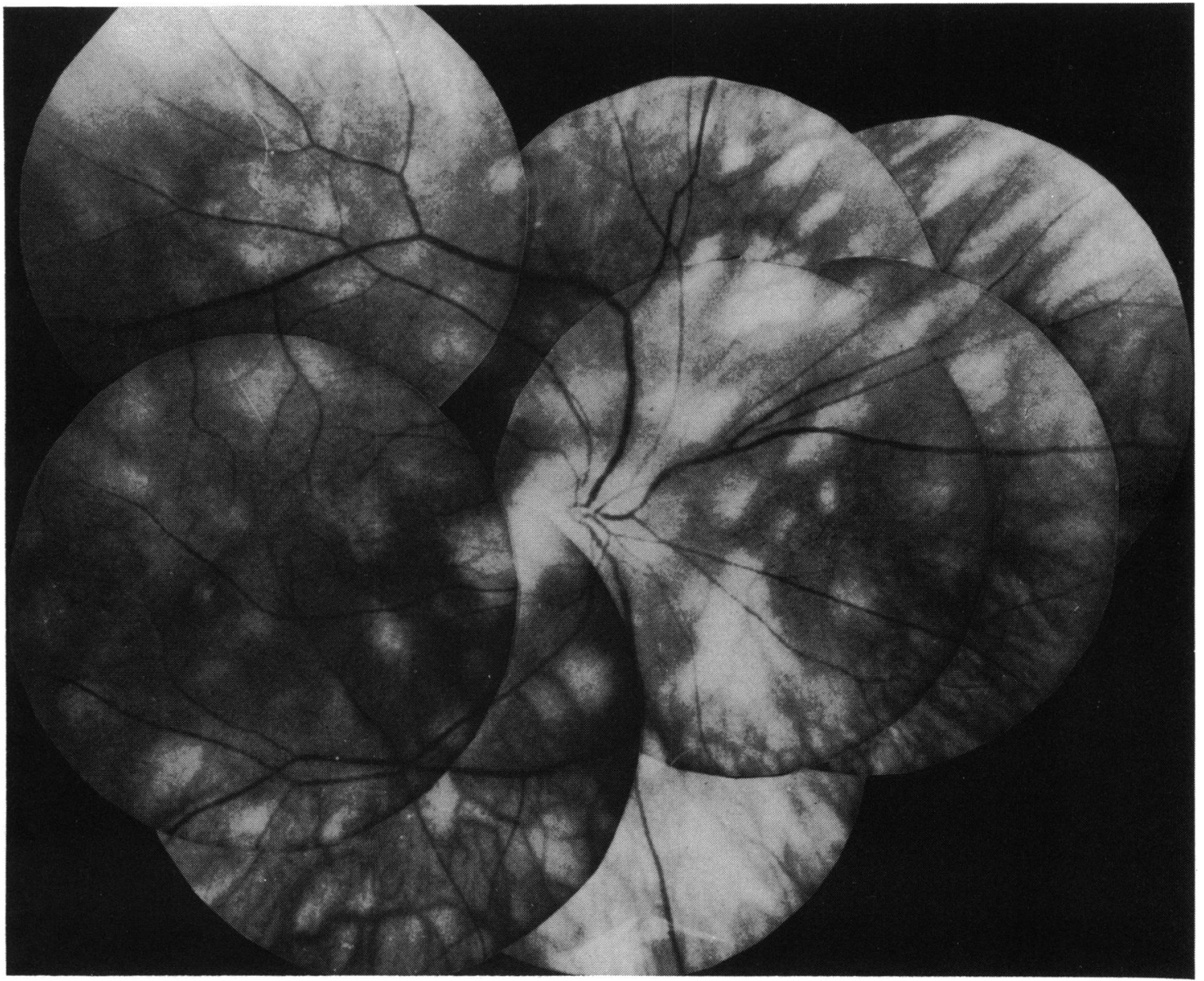

Fig. 1 Case 1. Red-free composite picture of the right eye: typical patches of birdshot retinochoroidopathy, narrowing of retinal vessels, optic disc margins blurred.

ophthalmoscopically. During the late phases of the angiogram bilateral leakage of dye from the capillaries of the optic nerve head was evident.

In addition there was a juxtapapillary retinal serous detachment surrounded by deep haemorrhage in the left eye which did not extend into the fovea. A deep greyish lesion, slightly elevated, was located in the centre of the detachment (Fig. 2). A fluorescein angiogram showed an early deep hyperfluorescence, increasing markedly in late phase, located at about $1000 \mu \mathrm{m}$ from the centre of the foveola (Figs. 3A, B). The Goldmann visual field showed a relative paracentral scotoma. Colour testing showed a mild acquired dyschromatopsia. Laser photocoagulation was applied to the neovascular membrane.

CASE 2

A 43-year-old woman had had blurred vision for 3 years. In 1978 she was treated with corticosteroids for vitritis and papillitis. Her medical history was significant in that she had hypertension treated by methyldopa. Her best corrected visual acuity was in January 1980, RE 6/9 (+1.00) and LE 6/6 (+1.00). Biomicroscopy disclosed vitreous cells bilaterally. On fundus examination the typical depigmented lesions extended from the optic disc to the equator. Some patches involved the posterior pole (Fig. 4).

In the right eye there was a juxtapapillary serous detachment, 1 disc diameter in size, which did not extend into the fovea. In the centre of the detachment the angiogram showed an early hyperfluorescence of a deep neovascular membrane extending temporally (Figs. 5A, B) with dye leakage during the study (Fig. 5C).

\section{CASE 3}

A 58-year-old woman complained of markedly decreased visual acuity in both eyes over several 


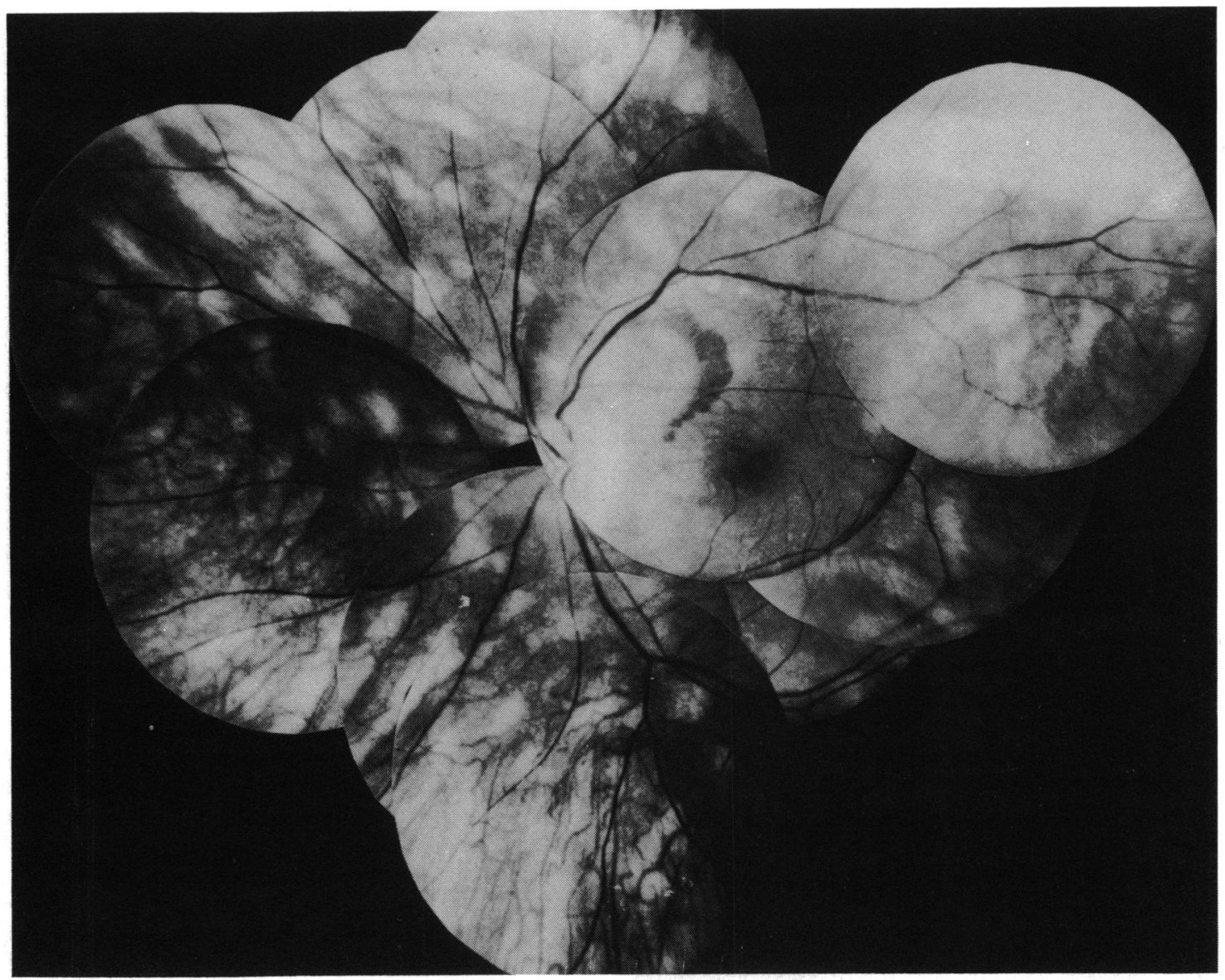

Fig. 2 Case 1. Red-free composite picture of the left eye: symmetrical aspect of retinal periphery associated to a juxtapapillary retinal detachment outlined with a subretinal haemorrhage.

years. In May 1981 her best corrected visual acuity was in RE 1/40 and in LE 1/20. Slit-lamp examination disclosed cells in the anterior chamber and in the vitreous. In both eyes the typical subretinal patches of birdshot retinochoroidopathy were present. In her right eye there was a macular scar probably secondary to subretinal new vessels. In the left eye a serous retinal detachment extended from the temporal margins of the disc toward the macula. A haemorrhage was located in the macula (Fig. 6).

In October 1981 the visual acuity in the left eye was unchanged. A fundus examination showed the extension of the serous detachment outlined by a subretinal haemorrhage temporally to the macula (Fig. 7A). On fluorescein angiography a deep early hyperfluorescence underneath the macula was visible (Fig. 7B). This hyperfluorescence increased during the late phases (Fig. 7C). From the margin of the optic nerve a glial proliferation was extending towards the macula. These angiographic features implied the' presence of subretinal neovascular tissue.

\section{Discussion}

The occurrence of subretinal new vessels in uveitis has been recorded at a cicatricial stage of focal choroiditis.

In 'presumed ocular histoplasmosis syndrome'43 the new vessels usually arise from the atrophic scars (histospots). In toxoplasmosis ${ }^{44}$ the subretinal new vessels originate from the retinal choroiditis focus. Such cases have been published of patients with infection by toxocara canis, ${ }^{1013}$ syphilis, ${ }^{14}$ and tuberculosis. In all these cases the retinal pigment epithelium and Bruch's membrane were partially or totally destroyed at the site of the atrophic scars. Thus the new vessels of choroidal origin had access to the subepithelial or subretinal space of the macular area. 


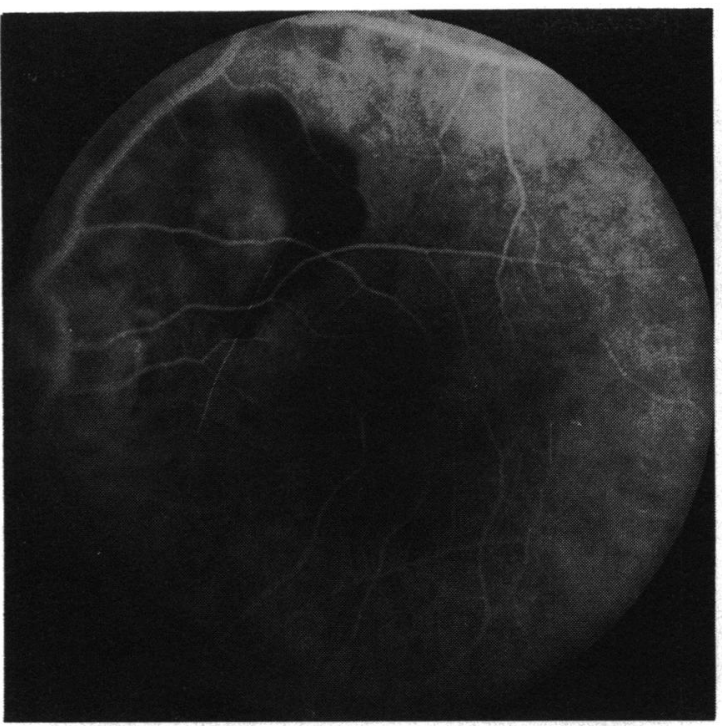

Fig. 3A

Fig. 3 Case 1. Juxtapapillary subretinal neovascularisation subretinal new vessels and from the optic disc (B).

Chronic intraocular inflammation may be associated with a diffuse and extensive depigmentation of the retinal pigment epithelium. ${ }^{2}$ In diffuse and nonspecific chronic uveitis the occurrence of subretinal new vessels is uncommon. Few cases have

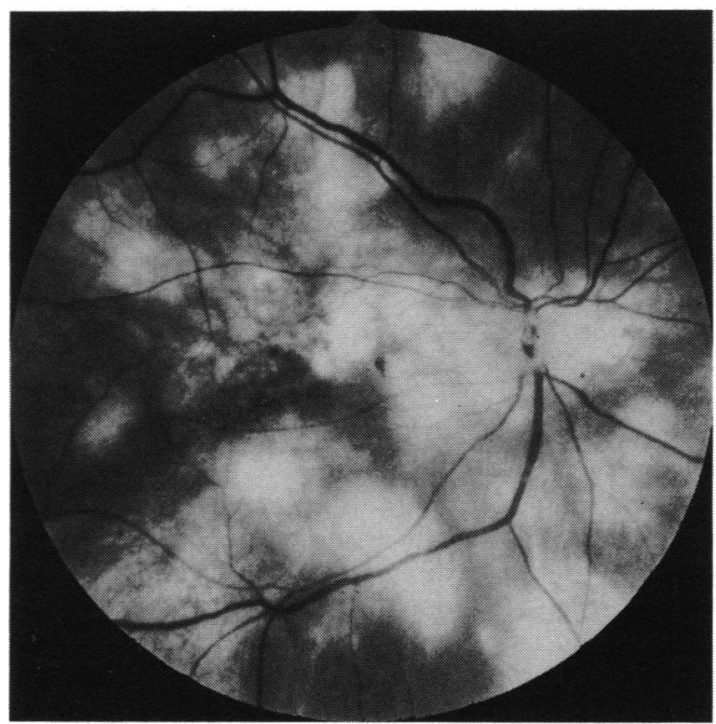

Fig. 4 Case 2. Red-free frame of the right eye: patches of birdshot retinochoroidopathy involving also the posterior pole associated with a temporal juxtapapillary serous detachment (courtesy of Dr Quentel).

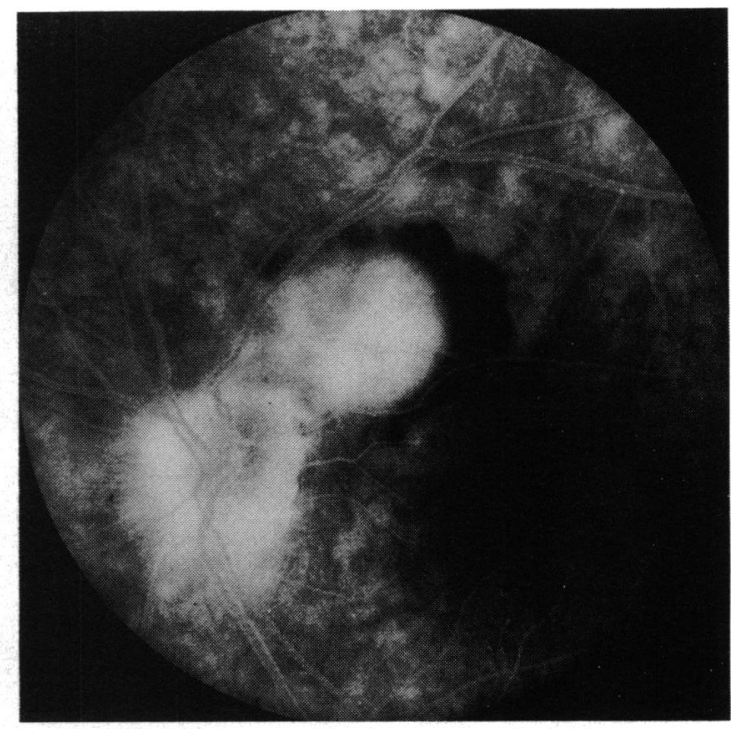

Fig. 3B

A). Leakage of dye at the late phase of angiogram from the

been published-one with peripapillary neovascularisation by Schwartz, ${ }^{14}$ and 2 by Augsburger ${ }^{15}$ (one with peripapillary neovascularisation, one with bilateral macular new vessels). These authors reported pigment epithelium disturbances of the posterior pole which evoked atrophic scars. They believe that chronic ocular inflammation stimulated the proliferation of subretinal new vessels located near the atrophic patches involving the pigment epithelium and the choriocapillaris.

The characteristic feature of the birdshot retinochoroidopathy is the existence of yellow-white or faintly orange patches of depigmentation. These flat patches are usually symmetrically distributed in both eyes, scattered in the postequatorial part of the fundus, and often more numerous in the area nasal to the optic disc than elsewhere. There is no evidence of hyperpigmentation within the lesion or at their margins. There is no slit-lamp evidence of thinning either of the retina or of the choroid in the area of the patches. Large choroidal blood vessels are usually observed within the lesion in white light but the overlying retinal vessels appear normal.

During the early phase of angiography the patches show no evidence of alteration in the normal background of choroidal fluorescence. ${ }^{45}$ There is no evidence either of early hypofluorescent areas to suggest choriocapillaris atrophy, or early hyperfluorescent areas that might be expected if there were depigmentation of the pigment epithelium or loss of function of the pigment epithelial barrier. This 


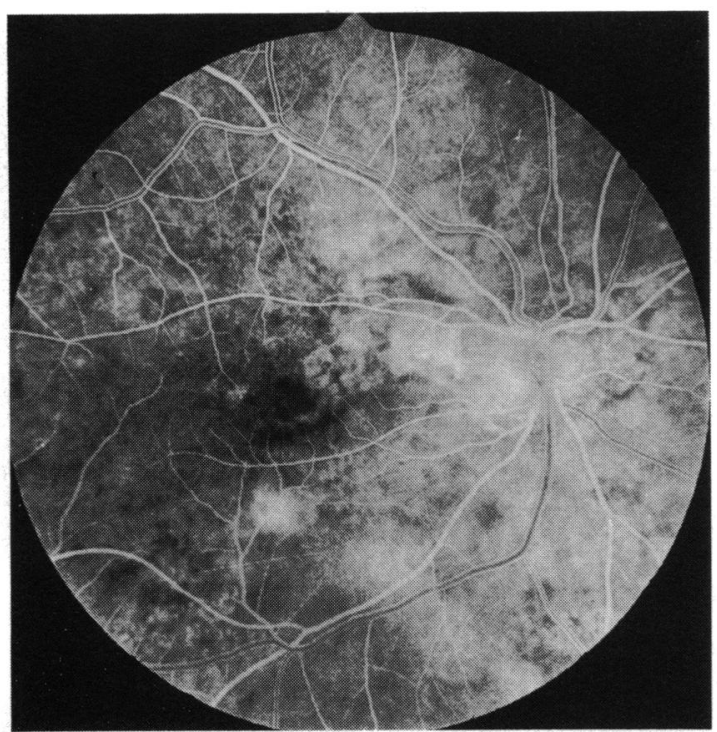

Fig. 5A

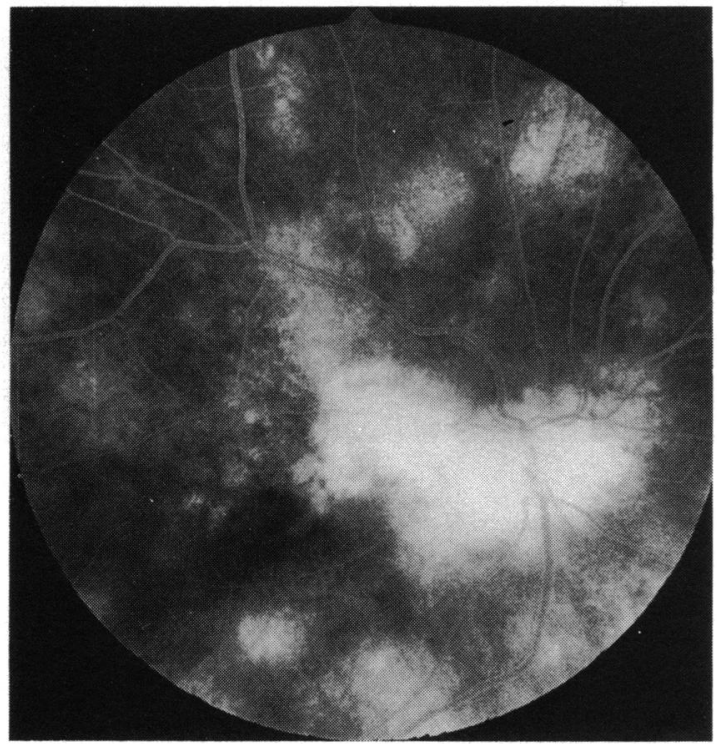

Fig. 5C

would be in accord with the suggestion by Gass ${ }^{42}$ that the pallor of the lesions was due to loss of pigment from choroidal melanocytes. Such an appearance could also be produced by the presence of abnormal deposits beneath the pigment epithelium more evident in white light. Such deposits may induce neovascularisation or alter Bruch's membrane so that a barrier to new vessel membrane growth is destroyed.

The peripapillary location of the new vessels in all 3 cases may suggest that inflammation of the nerve

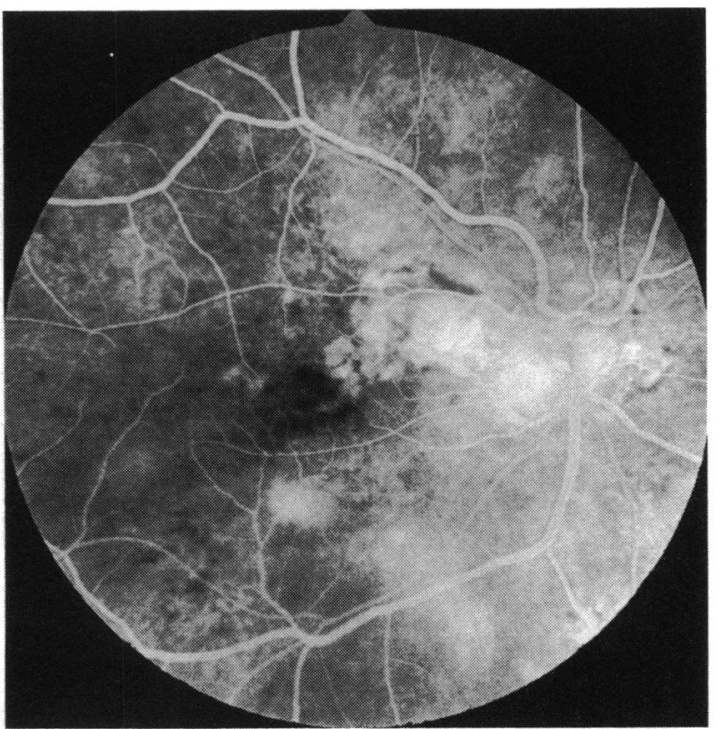

Fig. 5B

Fig. 5 Case 2. Early hyperfluorescence superior temporally to the optic disc (A). Leakage of dye from the subretinal new vessels $(\mathrm{B}, \mathrm{C})$.

head and of the peripapillary region is of importance in the genesis of neovascularisation. There is no evidence that inflammation has little if any effect on the retinal pigment epithelium, but it has on Bruch's membrane. Recently it has been suggested ${ }^{41}$ that although the occurrence of birdshot retinochoroidopathy is genetically predisposed, retinal autoimmunity plays a role in the manifestation of the disease.

Serous detachment and haemorrhages have been 


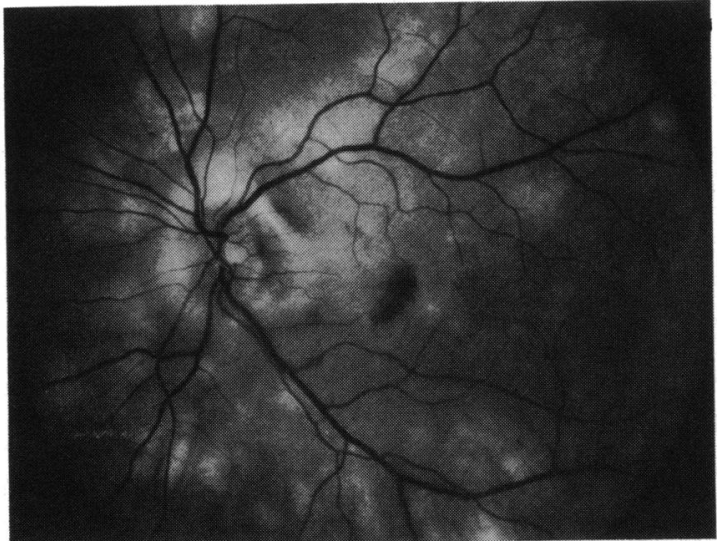

Fig. 6 Case 3. Red-free photograph: retinal serous detachment temporal to the optic nerve outlined by a haemorrhage; scattered birdshot patches.

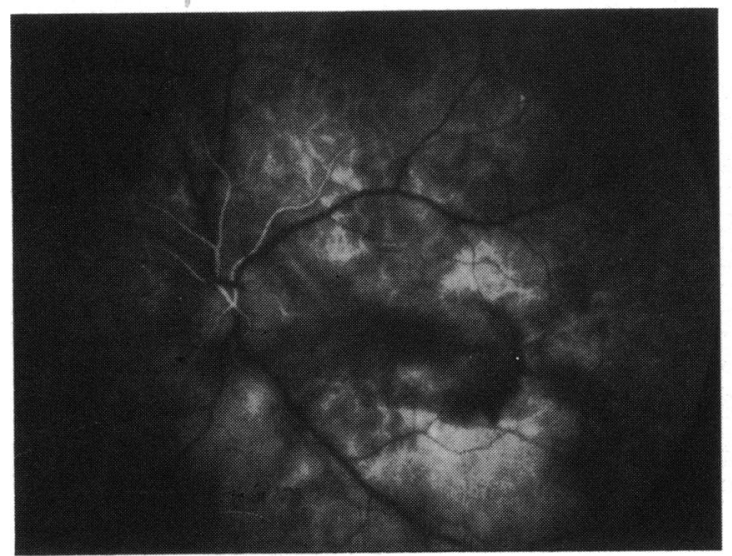

Fig. 7B

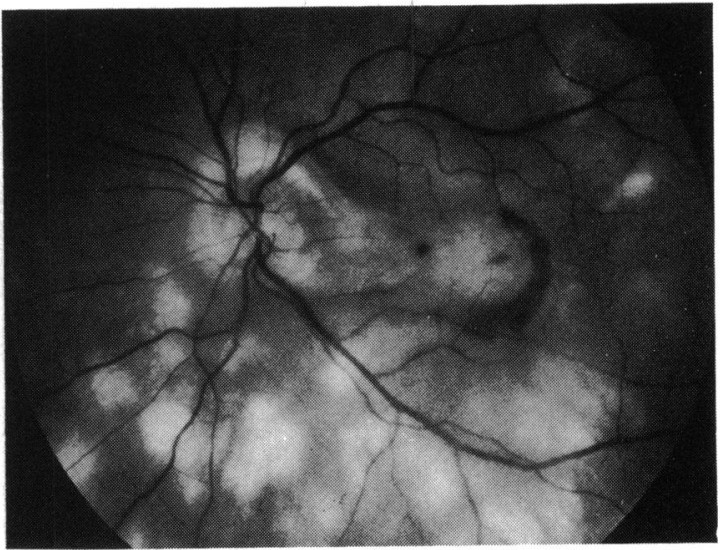

Fig. 7A

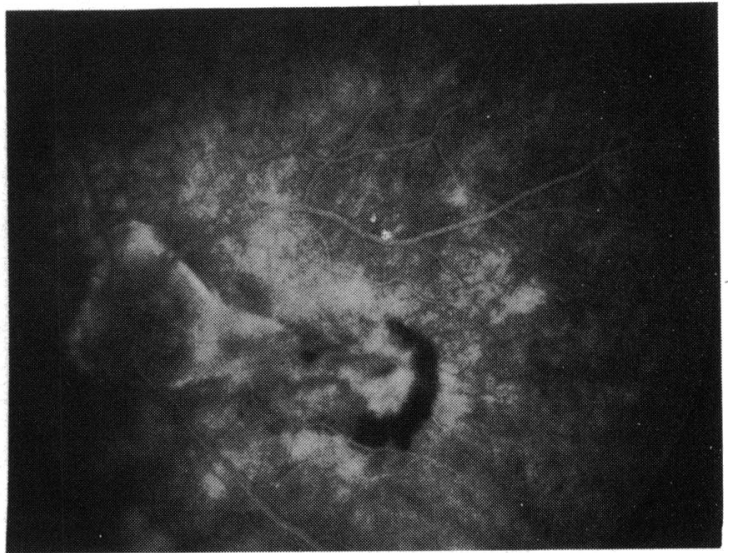

Fig. 7C

Fig. 7 Case 3. Five months later: extension of the serous detachment on the other side of the foveola on red-free photograph (A). Early hyperfluorescence in the macula outlined by a deep haemorrhage (B). Late phase: leakage of dye in the macula and fibrous tissue extending from the optic disc (C).

reported in birdshot retinochoroidopathy, but in no case described were subretinal new vessels identified. The decreased visual acuity in this disease, with many manifestations and a broad spectrum, may be due to optic atrophy or cystoid macular oedema. Subretinal neovascularisation is another possible sightthreatening complication.

Our thanks are due to A. M. Simonian and I. Nourry for their patience and competence in preparing the manuscript; $L$. Lechevalier and B. Allard for photographic assistance. We are grateful to Professor A. Bird for valuable discussions and advice.

\section{References}

1 Ryan SJ, Maumenee AE. Birdshot retinochoroidopathy. Am J Ophthalmol 1980; 89: 31-45.
2 Gass JDM. Vitiliginous chorioretinitis. Arch Ophthalmol 1981; 99: 1778-87.

3 Kaplan HJ, Aaberg TM. Birdshot retinochoroidopathy. Am J Ophthalmol 1980; 90: 773-82.

4 Schatz H, Burton TC, Yannuzzi LA, Rabb MF. Interpretation of fundus fluorescein angiography. Birdshot choroidopathy associated with cystoid edema. St Louis: Mosby, 1978: 598-9.

5 Gass JDM. Pathogenesis of disciform detachment of the neuroepithelium. Am J Ophthalmol 1967; 63: 563-71.

6 Schlaegel TF, Weber JC. Follow-up study of presumed histoplasmic choroiditis. Am J Ophthalmol 1971; 71: 1192-5.

7 Schlaegel TF. Histoplasmic choroiditis. Ann Ophthalmol 1974; 63: $237-52$.

8 Gass JDM, Wilkinson CP. Follow-up study of presumed ocular histoplasmosis. Trans Am Acad Ophthalmol Otolaryngol 1972; 76: 672-94.

9 Krill AE, Archer D. Choroidal neovascularization in multifocal (presumed histoplasmin) choroiditis. Arch Ophthalmol 1970; 84: 595-604. 
10 Gass JDM. Stereoscopic atlas of macular diseases. St Louis: Mosby, 1970.

11 Chisholm IH, Gass JDM, Hutton WL. Late stage of serpiginous (geographic) choroiditis. Am J Ophthalmol 1976; 82: 343-51.

12 Jampol LM, Orth D, Daisy MJ, Rabb MF. Subretinal neovascularization with geographic (serpiginous) choroiditis. $\mathrm{Am} \mathrm{J}$ Ophthalmol 1979; 88: 683-9.

13 Ashton N. Larval granulomatosis of the retina due to toxocara. Br J Ophthalmol 1960; 44: 129-48.

14 Schwartz PL, Gragoudas ES, Lapus JV. Peripapillary subretinal neovascularization in chronic uveitis. Arch Ophthalmol 1978; 96: 836-8.

15 Augsburger JJ, Benson WE. Subretinal neovascularization in chronic uveitis. Albrecht von Graefes Arch Klin Ophthalmol 1980; 215: 43-51.

16 Sanders TE, Gaya J, Newmann H. Hemorrhagic complication of drusen of the optic disc. Am J Ophthalmol 1971; 71: 204-16.

17 Wise GN, Henkind P, Alterman M. Optic disc and subretinal hemorrhage. Trans Am Acad Ophthalmol Otolaryngol 1974; 78: 212-9.

18 Gass JDM. Pathogenesis of disciform detachment of the neuroepithelium IV. Disciform detachment secondary to heredodegenerative, neoplastic and traumatic lesions of the choroid. Am J Ophthalmol 1967; 63: 689-711.

19 Pro M, Shields J, Tomer TL. Serous detachment of the macula associated with presumed choroidal nevi. Arch Ophthalmol 1978; 96: 1374-7.

20 Waltmann DD, Gitter KA, Yannuzzi L, Schatz H. Choroidal neovascularization associated with choroidal nevi. Am J Ophthalmol 1978; 85: 704-10.

21 Snip RC, Green WR, Jaegers KR. Choroidal nevus with subretinal pigment epithelial neovascular membrane and a positive ${ }^{32} \mathrm{P}$ test. Ophthalmol Surg 1979; 3: 33-42.

22 Fuller B, Gitter KA. Traumatic choroidal rupture with late serous detachment of the macula. Arch Ophthalmol 1973; 89: 354-7.

23 Smith RE, Kelley JS, Harbin TS. Late macular complications of choroidal ruptures. Am J Ophthalmol 1974; 77: 650-8.

24 Klien BA. Symposium on macular disease: clinical manifestations. 2. The macular lesion in angioid streaks (GroenbladStranberg syndrome). Trans Am Acad Ophthalmol Otolaryngol 1962; 69: 620

25 Gass JDM, Clarkson JG. Angioid streaks and disçiform macular detachment in Paget's disease (osteitis deformans). Am J Ophthalmol 1960; 49: 540-70.

26 Gass JDM. Differential diagnosis of intraocular tumors. St Louis: Mosby, 1975.

27 Klein R, Lewis RA, Meyers SM, Meyers FL. Subretinal neovascularization associated with fundus flavimaculatus. Arch. Ophthalmol 1978; 96: 2054-7.

28 Noble KG, Scher BM, Carr RE. Polymorphous presentations in vitelliform macular dystrophy: subretinal neovascularization and central choroidal atrophy. Br J Ophthalmol 1978; 62: 561-70.

29 Francois J, De Laey JJ, Cambie E, Hanssens M. VictoriaTroncoso $\mathrm{V}$. Neovascularization after argon laser photocoagulation of macular lesions. Am J Ophthalmol 1975; 79: 206-10.

30 Fine SL, Patz A, Orth DH, Klein MJ, Finkelstein D, Yassur Y. Subretinal neovascularization developing after prophylactic argon laser photocoagulation of atrophic macular scars. Am J Ophthalmol 1976; 82: 352-7.

31 Geeraets WJ, Dupont Guerry III Angioid streaks and sickle cell disease. Am J Ophthalmol 1960; 49: 540-70.

32 Gerde LS. Angioid streaks in sickle cell trait hemoglobinopathy. Am J Ophthalmol 1974; 77: 462-4.

33 Nagmal KS, Asdourian G, Goldbaum M, Apple D, Goldberg M. Angioid streaks and sickle cell haemoglobinopathies. $\mathrm{Br} J$ Ophthalmol 1976; 60: 31-4.

34 Jamison RR. Subretinal neovascularization and papilledema associated with pseudotumor cerebri. Am J Ophthalmol 1978; 85: 78-81.

35 Morse PH, Leveille AS, Antel JP, Burch JV. Bilateral juxtapapillary subretinal neovascularization associated with pseudotumor cerebri. Am J Ophthalmol 1981; 91: 312-7.

36 Deutman AF, Grizzard WS. Rubella retinopathy and subretinal neovascularization. Am J Ophthalmol 1978; 85: 82-7.

37 Frank KE, Purnell EW. Subretinal neovascularization following rubella retinopathy. Am J Ophthalmol 1978; 86: 462-6.

38 Orth DH, Fishman GA, Segall M, Bhatt A, Yassur Y. Rubella maculopathy. Br J Ophthalmol 1980; 64: 201-5.

39 Michelson JB, Michelson PE, Chisari FV. Subretinal neovascular membrane and disciform scar in Behçet's disease. Am J Ophthalmol 1980; 90: 182-5.

40 Carlson MR, Kerman BM. Hemorrhagic macular detachment in Vogt-Koyanagi-Harada syndrome. Am J Ophthalmol 1977; 84: $632-5$

41 Nussenblatt RB, Mittal KK, Ryan S, Green RW, Maumenee EA. Birdshot retinochoroidopathy associated with HLA-A29 antigen and immune responsiveness to retinal S-Antigen. $A m \mathrm{~J}$ Ophthalmol 1982; 94: 147-58.

42 Gass JDM. Pathogenesis of disciform detachment of the neuroepithelium. V. Disciform macular degeneration secondary to focal choroiditis. Am J Ophthalmol 1967; 63: 661-87.

43 Lewis ML, Van New Kirk MR, Gass JDM. Follow-up study of presumed ocular histoplasmosis syndrome. Ophthalmology 1980; 87: 390-9.

44 Fine SL, Owens SL, Haller JA, Knox DL, Patz A. Choroidal neovascularization as a late complication of ocular toxoplasmosis. Am J Ophthalmol 1981; 91: 318-22.

45 Amalric $P$, Cuq $G$. Une forme très particulière de chorioretinopathie en grains de riz. Bull Soc Ophtalmol Fr 1981; 1: $131-4$. 